\title{
Gaya Hidup dan Hipertensi Pada Lanjut Usia di Kecamatan Kasihan Bantul Yogyakarta
}

\author{
Edi Sampurno Ridwan', Esti Nurwanti \\ 1,2 Sekolah Tinggi IImu Kesehatan Alma Ata Yogyakarta \\ Jalan Ringroad Barat Daya No 1 Tamantirto, Kasihan, Bantul Yogyakarta
}

\begin{abstract}
Abstrak
Gaya hidup merupakan faktor yang berperan penting terhadap kejadian beberapa penyakit kronic seperti hipertensi. Penelitian ini merupakan peneltian observasional analitik dengan desain cross-sectional. Sebanyak 9887 populasi yang ada, dengan menggunakan rumus slovin didapatkan 100 reponden, jumlah responden tiap desa ditentukan dengan tehnik stratified random sampling, sedangkan sample tiap posyandu ditentukan dengan tehnik random sampling. Variabel yang diukur adalah aktifitas fisik, konsumsi junk food, dan merokok yang masing masing menggunakan kuesioner FFQ (food frequency questionnaire), International Physical Activity Questionaire, dan kuesioner merokok. Data dianalisis menggunakan Chi-Square dan didapatkan hasil bahwa mengkonsumsi junk food mempunyai 4 kali lipat terjainya hipertensi pada lansia $(0 R, 4,083)$, perilaku sendentari ( $p$ value; 0.004) dan merokok ( $p$ value; 0.001) mempunyai signifikansi atas terjadinya hipertensi pada lansia di kecamatan Kasihan, Bantul, Yogyakarta. Hasil penelitian dapat disimpulkan bahwa konsumsi makanan junk food, sendetari behavior, dan perilaku merokok merupakan faktor resiko terjadinya hipetensi. Oleh karena itu diperlukan program promosi kesehatan yang lebih berfokus pada perbaikan gaya hidup masyarakat terutama kelompok umur lanjut usia.

Kata kunci: Gaya Hidup, Lanjut Usia, Hipertensi.
\end{abstract}

\section{Life style and Hypertension on elderly in Kasihan Bantul Yogyakarta}

\begin{abstract}
Life style plays important role toward emerging chronic diseases including hypertension. This is an observationanalytical research using cross-sectional design. It was 100 respondents in the research obtained using Slovin formula from 9887 population. Stratified random sampling and simple random sampling were assigned to select sample. Variables were measured with FFQ (food frequency questionnaire), International Physical Activity Questionnaire, and Smoking Questioner. Data was analyzed using Chi-Square and the result was junk food consumption leading to 4 times risk for hypertension (OR, 4,083). In addition, sedentary behavior ( $p$ 0.004 ) and smoking ( $p$ 0.001) were significant factors to lead hypertension for older people. Conclusion, junk food, sedentary behavior, and smoking habits can be the risk factors of hypertension. Thus, it is imperative to develop health promotion program focusing on the changing life style for aged group.
\end{abstract}

Keywords: Life Style, Elderly, Hypertension.

Info Artikel:

Artikel dikirim pada 13 Desember 2013

Artikel diterima pada 16 Desember 2013

\section{Pendahuluan}

Gaya hidup merupakan faktor yang berperan penting terhadap kejadian beberapa penyakit kronic seperti hipertensi. Perubahan gaya hidup ini tidak lepas dari bergesernya kebiasaan masyarakat dalam kehidupan sehari hari. Baik di pedesaan atau di perkotaan kecenderungan untuk kurang melakukan aktifitas fisik, kebiasaan merokok, mengkonsumsi makanan siap saji sudah sangat tinggi. Menurut data Riskesdas tahun 2013. ${ }^{1}$ Daerah Istimewah Yogyakarta 
(DIY) mempunyai kecenderungan terjadi hipertensi yang tinggi. Dari seluruh propinsi di Indonesia, jumlah penderita hipertensi DIY berada pada urutan tertinggi ke tiga setelah Nusa Tenggara Timur (NTT) dan Kalimantan Selatan (Kalsel). Walaupun angka kejadian hipertensi di Indonesia secara umum menurun tapi hipertensi masih merupakan penyakit yang dominan di masyarakat.

Beberapa faktor yang merupakan bagian dari gaya hidup adalah konsumsi junk food yang saat ini menjadi sangat popular di lingkungan anak sampai orang dewasa. Saat ini terjadi perubahan pola konsumsi makanan pada lansia dengan kecenderungan untuk memilih makanan yang mempunyai komposisi tinggi kalori, tinggi lemak, rendah serat dan sebagainya. Jenis makanan junk food banyak digemari oleh para lansia karena makanan junk food dianggap lebih praktis, enak dan tidak menghabiskan waktu lama sehingga dapat disajikan kapan dan dimana saja. ${ }^{2}$ Makanan junk food mengandung natrium dalam jumlah yang besar yang dapat meningkatkan volume darah di dalam tubuh sehingga jantung harus memompa darah lebih kuat yang menyebabkan tekanan darah lebih tinggi (hipertensi). Menurut Fatmah ${ }^{3}$, makanan yang kurang seimbang akan memperburuk kondisi lansia yang secara alami memang sudah menurun dibandingkan usia dewasa, kebutuhan gizi pada lansia umumnya mengalami penurunan lebih rendah karena adanya penurunan metabolisme basal. Hal ini didukung oleh penelitian Erlyna, dkk ${ }^{4}$ bahwa kebiasaan konsumsi makanan berlemak dan bergaram tinggi merupakan faktor risiko terjadinya hipertensi.

Faktor selanjutnya yang mempunyai korelasi dengan kejadian hipertensi adalah aktifitas fisik yang kurang aktif (Sedentary Behavior). Perilaku kurang aktif merupakan faktor resiko independen untuk penyakit kronis dan secara keseluruhan diperkirakan merupakan faktor yang meningkatkan morbiditas secara global. Menurut World Health Organisation ${ }^{5}$, akibat dari perilaku sendetary (sendetary Behaviour) terjadinya hipertensi. Strategi pendukung untuk mengurangi sendetary behavior di golongan usia lanjut adalah peningkatan tingkat ekonomi dan aktif secara fisik. Data Riskesdas tahun $2007{ }^{6}$ menunjukkan bahwa cecara nasional, hampir separuh penduduk $(48,2 \%)$ kurang melakukan aktifitas fisik atau mempunyai perilaku sedentary behavior. Sesuai dengan kelompok umur disebutkan bahwa golongan umur 65 tahun ke atas dikategorikan kurang aktifitas fisik paling tinggi sebanyak $(76 \%)$ dan umur $10-40$ tahun $(66,9 \%)$. Sedangkan berdasarkan tingkat pendidikan, semakin tinggi pendidikan semakin tinggi prevalensi kurang aktifitas fisik. Prevalensi kurang aktifitas fisik penduduk perkotaan $(57,6 \%)$ lebih tinggi dibanding pedesaan.
Masalah diatas mencerminkan bahwa gaya hidup sehat sangat perlu mendapatkan perhatian dan penelitian di bidang ini akan memberikan dampak yang luas terhadap derajat dan kualitas hidup masyarakat.

\section{Bahan dan Metode}

Jenis penelitian ini merupakan penelitian yang bersifat analitik observasional dengan desain cross sectional. Penelitian ini disebut penelitian observasional karena peneliti hanya mengamati subjek penelitian dan mencari data berkaitan dengan penelitian tanpa memberikan perlakuan terhadap subjek penelitian, dan menggunakan desain cross sectional karena dalam pengumpulan datanya dilakukan dalam satu periode waktu tertentu ${ }^{7}$. Penelitian ini dilakukan pada tanggal 18 April -20 Mei 2014, di wilayah kecamatan Kasihan Bantul yang meliputi 4 desa, dan 64 posyandu lansia. Populasi dalam penelitian ini adalah semua lansia yang ada di Kecamatan Kasihan Bantul Yogyakarta dengan jumlah 9.887 orang. Sebanyak 100 responden dalam penelitian ini didapatkan dengan menggunakan rumus Slovin dengan tingkat kepercayaan 0,1 . Responden tiap dusun didapatkan dengan menggunakan tehnik Proportional Stratified Random Sampling dengan rincian sebagai berikut; desa Tirtonirmolo sebanyak 23, desa Ngestiharjo sebanyak 28, desa Bangun Jiwo sebanyak 27 , desa Tamantirto sebanyak 22 orang. Random sampling digunakan untuk mendapatkan sample penelitian tiap-tiap posyandu lansia.

Variabel bebas pada penelitian adalah aktifitas fisik, konsumsi junk food, dan kebiasaan merokok sedangkan variable terikat adalah hipertensi. Instrument yang digunakan dalam penelitian ini adalah kuesioner meliputi FFQ (food frequency questionnaire), International Physical Activity Questionaire, dan kuesioner merokok.

\section{Hasil dan Pembahasan}

Hasil penelitian disajikan dalam tabel dibawah ini:

1. Data demografi kecamatan kasihan Bantul

Kecamatan Kasihan Bantul berada di sebelah utara ibu kota Kabupaten Bantul dengan luas wilayah 3.437.957 Ha dan berada di dataran rendah. Jumlah kepala keluarga di kecamatan Kasihan sebanyak 15.559 KK (kepala keluarga). Jumlah keseluruhan penduduk Kecamatan Kasihan adalah 77.261 orang dengan jumlah penduduk laki-laki sebanyak 38.582 orang dan penduduk perempuan sebanyak 38.679 
orang. Jumlah seluruh lansia yang ada di Kecamatan Kasihan Bantul yaitu 9.887 orang. Wilayah kecamatan Kasihan Bantul terdapat empat desa antara lain Desa Tirtonirmolo terdiri dari 15 posyandu lansia dengan jumlah lansia 2.231, Desa Ngestiharjo terdiri dari 20 posyandu lansia dengan jumlah lansia 2.815, Desa Bangunjiwo terdiri dari 16 posyandu lansia dengan jumlah lansia 2.653, dan Desa Tamantirto terdiri dari 12 posyandu lansia dengan jumlah lansia 2.187.

\section{Data Univariat}

Table 1.1 Distribusi frekwensi konsumsi junk food pada lansia berdasarkan usia, jenis kelamin, pendidikan, dan pekerjaan

\begin{tabular}{lccc}
\hline Karakteristik & Kategori & $\begin{array}{c}\text { Frekwensi } \\
(\mathbf{N})\end{array}$ & $\begin{array}{c}\text { Persentase } \\
\text { (\%) }\end{array}$ \\
\hline Usia (tahun) & $60-70$ & 71 & 71 \\
& $71-84$ & 29 & 29 \\
& Jumlah & 100 & 100 \\
\hline Jenis kelamin & Laki-laki & 28 & 28 \\
& Perempuan & 72 & 72 \\
& Jumlah & 100 & 100 \\
\hline Pendidikan & Dasar & 42 & 42 \\
& Menengah & 32 & 32 \\
& Tinggi & 26 & 26 \\
& Jumlah & 100 & 100 \\
\hline Pekerjaan & Bekerja & 63 & 63 \\
& Tidak Bekerja & 37 & 37 \\
& Jumlah & 100 & 100 \\
\hline
\end{tabular}

Konsumsi junk food paling banyak dikonsumsi oleh golongan umur lanjut usia antara umur 60-70 tahun sebanyak $71 \%$, perempuan merupakan jenis kelamin yang mengkonsumsi junk food tertinggi sebanyak $72 \%$. Sedangkan pada kelompok lansia yang bekerja dan berpendidikan dasar junk food dikonsumsi sebanyak $63 \%$ dan $42 \%$.

Table1.2 Distribusi Konsumsi Junk Food pada Lansia berdasarkan Jenis dan Frekwensi Makanan

\begin{tabular}{lcc}
\hline Jenis Makanan & \multicolumn{2}{c}{ Frekuensi Makanan } \\
\cline { 2 - 3 } & Jumlah & $\%$ \\
\hline Mengandug tinggi sodium & 50 & 45,9 \\
Makanan kemasan & 35 & 32,1 \\
Olahan daging & 12 & 11 \\
Kripik kentang & 7 & 6,4 \\
Makanan kaleng & 5 & 4,6 \\
Burger & & \\
\hline Mengandung tinggi lemak jenuh & 86 & 76,1 \\
Gorengan & 17 & 15 \\
Makanan dibakar & 7 & 6,2 \\
Lemak daging & 3 & 2,7 \\
Olahan keju & & \\
\hline Mengandung tinggi gula & 37 & 62 \\
Kue basah & 12 & 19 \\
Es krim & 12 & 19 \\
Biskuit & \multicolumn{2}{c}{}
\end{tabular}

Makanan kemasan merupakan jenis makanan yang di pilih oleh lansia sebanyak $50 \%$, dan makanan yang mengandung lemak jenuh merupakan jenis makanan yang paling tinggi dikonsumsi yaitu $86 \%$. Sedangkan ke basah merupakan jenis junk food yang dipilih oleh $27 \%$ responden.

Table 1.3 Jumlah Lansia merokok di Kecamatan Kasihan

\begin{tabular}{lcc}
\hline \multirow{2}{*}{ Merokok } & \multicolumn{2}{c}{ Frekuensi Merokok } \\
\cline { 2 - 3 } \multicolumn{1}{c}{ Jumlah } & $\%$ \\
\hline Merokok Ringan & 29 & 29 \\
Merokok Sedang & 26 & 26 \\
Merokok Berat & 45 & 45 \\
Jumlah & 100 & 100 \\
\hline
\end{tabular}

Lansia di kecamatan kasihan lebih banyak sebagai perokok ringan dan sedang yaitu sebanyak $55 \%$ sedangkan perokok berat dilakukan oleh $45 \%$ lansia.

Table 1.4 Kejadian Hipertensi Pada Lansia Berdasarkan Usia, Jenis Kelamin, Pendidikan, dan Pekerjaan

\begin{tabular}{lccccc}
\hline \multirow{2}{*}{ Karakteristik } & \multirow{2}{*}{ Kategori } & \multicolumn{4}{c}{ Hipertensi } \\
\cline { 3 - 6 } & & Ya & $\%$ & Tidak & \% \\
\hline Usia (tahun) & $60-70$ & 27 & 61,4 & 17 & 38,6 \\
& $71-84$ & 44 & 78,6 & 12 & 21,4 \\
\hline \multirow{2}{*}{ Jenis Kelamin } & Laki-laki & 23 & 82,1 & 5 & 17,9 \\
& Perempuan & 48 & 66,7 & 24 & 33,3 \\
\hline Pendidikan & Dasar & 29 & 69,0 & 13 & 31,0 \\
& Menengah & 24 & 75,0 & 8 & 25,0 \\
& Tinggi & 18 & 69,2 & 8 & 30,8 \\
\hline Pekerjaan & Bekerja & 46 & 73,0 & 17 & 27,0 \\
& Tidak & 25 & 67,6 & 12 & 32,4 \\
& Bekerja & & & & \\
\hline
\end{tabular}

Lanjut usia antara umur 71-84 berjenis kelamin perempuan menempati proporsi tertinggi mengalami hipertensi yaitu sebanyak $44 \%$ dan $48 \%$, sedangkan yang ber dasar dan menengah kejadaian hipetensi sangat tinggi yaitu $53 \%$ dari jumlah responden.

\section{Data Bivariat}

Tabel 1.6 Hubungan Konsumsi Junk food dan Hipertensi Pada Lansia

\begin{tabular}{lcccccccc}
\hline Hipertensi & \multicolumn{2}{c}{ Ya } & \multicolumn{2}{c}{ Tidak } & \multicolumn{2}{c}{ Total } & P & OR \\
\cline { 2 - 7 } Junk Food & $\mathrm{N}$ & $\%$ & $\mathrm{~N}$ & $\%$ & $\mathrm{~N}$ & $\%$ & Value & \\
\hline Sering & 49 & 61,1 & 24 & 32,9 & 73 & 100 & & \\
\hline Jarang & 9 & 33,3 & 18 & 66,7 & 27 & 100 & 0,002 & 4,083 \\
\hline Total & 58 & 58 & 42 & 42 & 100 & 100 & $\begin{array}{c}\text { Cl } 95 \% \\
(1,599-10,426\end{array}$ \\
\hline
\end{tabular}


Tabel 1.7 Hubungan aktifitas fisik dan Hipertensi pada lansia

\begin{tabular}{lccccccc}
\hline Hipertensi & \multicolumn{2}{c}{ Ya } & \multicolumn{2}{c}{ Tidak } & \multicolumn{2}{c}{ Total } & $\mathrm{P}$ \\
\cline { 2 - 7 } $\begin{array}{l}\text { Aktifitas } \\
\text { fisik }\end{array}$ & $\mathrm{N}$ & $\%$ & $\mathrm{~N}$ & $\%$ & $\mathrm{~N}$ & $\%$ & Value \\
\hline Ringan & 34 & 70,8 & 14 & 29,2 & 48 & 100 & 0.004 \\
Sedang & 14 & 63,6 & 8 & 36,4 & 22 & 100 & \\
Berat & 10 & 33,3 & 20 & 66,6 & 30 & 100 & \\
\hline & 58 & 58,0 & 42 & 42,0 & 100 & 100 & \\
\hline
\end{tabular}

Table 1.8 Hubungan Merokok dan Hipertensi Pada Lansia

\begin{tabular}{lccccccc}
\hline Hipertensi & \multicolumn{2}{c}{ Ya } & \multicolumn{2}{c}{ Tidak } & \multicolumn{2}{c}{ Total } & P \\
\cline { 1 - 6 } Merokok & $\mathrm{N}$ & $\%$ & $\mathrm{~N}$ & $\%$ & $\mathrm{~N}$ & $\%$ & Value \\
\hline Ringan & 10 & 34,5 & 19 & 65,5 & 29 & 100 & 0.001 \\
Sedang & 14 & 53,8 & 12 & 46,2 & 26 & 100 & \\
Berat & 35 & 77,8 & 10 & 22,2 & 45 & 100 & \\
\hline Total & 59 & 59.0 & 41 & 41.0 & 100 & 100 & \\
\hline
\end{tabular}

\section{Pembahasan}

Nilai OR sebesar 4,083 menunjukkan bahwa kelompok lansia yang mengkonsumsi junk food mempunyai 4 kali lipat resiko untuk mengalami hipertensi dibandingkan dengan mereka yang tidak mengkonsumsi junk food. Mengkonsumsi junk food merupakan faktor resiko hipertensi karena kandungan natrium pada makanan jenis ini pada umumnya sangat tinggi. Hal ini akan mempengaruhi peningkatan volume darah dalam tubuh sehingga akan terjadi peningkatan beban jantung atau jantung harus memompa darah yang lebih kuat. Menurut penelitian Fatmah [3], penurunan metabolism yang terjadi pada lansia disebabkan oleh penurunan kebutuhan metabolism basal tubuh. Rendahnya kualitas gizi akan mempengaruhi kondisi lansia.

Nilai signifikan 0,004 dengan kesalahan 0,05 mempunyai arti bahwa nilai $p$ lebih kecil dari taraf kesalahan, maka hipothesis diterima dan ada hubungan antra aktifitas fisik dan kejadian hipertensi. Peningkatan resiko hipertensi seiirng dengan faktor perubahan gaya hidup seseorang yang lebih memilih makanan yang tidak berkualitas gizi akibat dari kemudahan akses yang ada, serta rendahnya aktifitas fisik setiap hari. Perilaku sendentary menyebabkan ketidak seimbangan antara asupan energy dan pengeluaran energy. Nilai $P$ yang lebih besar dari pada taraf nilai kesalahan (0.05) merupakan gambaran bahwa ada hubungan yang sangat kuat kejadaian merokok dan kejadian hipertensi karena Ho ditolak dan Ha diterima.

\section{Simpulan dan Saran}

Gaya hidup yang kurang baik merupakan faktor resiko terjadinya hipertensi pada lansia di kecamatan kasihan bantul dari hasi penelitian didapatkan bahwa konsumsi junk food merupakan 4 kali lipat beresiko terhadap terjadinya hipertensi, demikina pula adanya sendetari behavior yang mengakibatkan rendahnya kegiatan fisik. Perilaku merokok yang merupakan konsumsi zat beracun secara sengaja sangat beresiko terjainya hipetensi.

Berdasarkan hasil penelitian bawah konsumsi makanan junk food, sendetari behavior, dan perilaku merokok merupakan fakto resiko terjadinya hipetensi. Oleh karena itu lansia sebainya diberikan pengertian yang cukup terhadap bahaya gaya hidup yang kurang sehat. Program promosi kesehatan akan sangat bermanfaat menurunkan kejadian hipertensi apabila ditujukan pada perbaikan gaya hidup masyarakat terutama kelompok umur lanjut usia.

\section{Daftar Pustaka}

1. Departemen kesehatan Kesehatan. Laporan Hasil Kesehatan Dasar (Riskesdas) Indonesia Tahun 2013. Badan Pengembangan dan Penelitian Kesehatan Depkes RI, 2013, Jakarta.

2. Husien, S. Junk Food Berkontribusi Terhadap Kinerja Buruk dan Obesitas . 2012.

3. Fatmah. Gizi Lanjut Usia. Penerbit Erlangga, 2010, Jakarta.

4. Erlyna, Herny dan Ari. Faktor-Faktor Risiko Hipertensi Primer Di Puskemas Tlogo Kulon Kota Semarang. Jurnal Kesehatan Masyarakat, 2012, 1(2):315-325.

5. World Health Organization. Physical Activity. WHO website 2010 (Dalam Http://Www.Who.Int/ Topics/Physical/Activity/En/. Diakses Tanggal 04 Februari 2014. Pukul 13.00 Wib).

6. Departemen Kesehatan RI. Laporan Hasil Kesehatan Dasar (Riskesdas) Indonesia Tahun 2007. Badan Pengembangan dan Penelitian Kesehatan Depkes RI.

7. Riwikdikdo, H. Statistika Kesehatan. Mitra Cendikia Press, 2008, Yogyakarta. 